\title{
Addressing key challenges to interdisciplinary research on water-related issues: Biologists' engagement and funding structure
}

\author{
Philippe C. BAVEYE ${ }^{1,2}$ \\ ${ }^{1}$ SIMBIOS Centre, Abertay University, Kydd Building, 40 Bell street, Dundee DD1 1 HG, Scotland, UK \\ ${ }^{2}$ Soil and Water Laboratory, Department of Civil and Environmental Engineering, Rensselaer Polytechnic Institute, 319 \\ MRC building, 110 8th street, Troy, New York 12180-3590, USA; e-mail: Baveye.RPI@gmail.com; P.Baveye@abertay.ac.uk
}

The breadth and depth of the various contributions to this special issue of Biologia provide convincing evidence of the vitality of biohydrology as a field of study. Building on, to some extent, and definitely complementing the very interesting research done in the area in recent years (Dekker et al. 2006; Hallett et al. 2009, 2010; Budagovskyi \& Novak 2011; Nagy 2011; Amiri et al. 2012; Hribik et al. 2012; Lichner et al 2012; Lichner 2013), the authors of these articles explore a number of topics related to the influence of biological processes on the dynamics of the water cycle and on water resources, and in some cases to the opposite effect, at a range of spatial and temporal scales. Many of the issues addressed have particular importance in the context of global climate change, given how little is known at the moment about the temperature dependence of their biological component, likely to be significantly larger than that of their hydrological aspects. It seems highly desirable for the field to expand greatly in the next few years, so that the many questions that are still unanswered, and are becoming more and more pressing at this stage, can be addressed and hopefully resolved. However, it seems that before this can happen, two significant roadblocks will need to be alleviated.

The first one is related to the interdisciplinary nature of the research dealing with biological influences on the water cycle and on water resources. By necessity, given their focus, articles dealing with biohydrology represent the successful outcomes of interdisciplinary investigations. At a time when "interdisciplinarity" has become a buzzword, when interdisciplinary research centers are cropping up on virtually every campus, and when hordes of researchers claim to be carrying out their work in an interdisciplinary mode, it may sound trivial to emphasize the fact that a piece of research qualifies as being interdisciplinary. Yet, buzzwords can be eminently deceiving. Anyone who has taken part in a project involving researchers from different disciplines knows just how difficult and frustrating such endeavors can be. A clear challenge from the outset is that each participant should learn enough about the other disciplines involved in the project to enable, in a timely manner, the development of a common language, which is a key to success. However, in practice, since everyone is overcommitted and has precious little time to read anymore, even to keep afloat in one's own area of expertise, this initial learning rarely if ever takes place, a common understanding never consolidates, and what started as a genuinely interdisciplinary effort tends to progressively morph, using the useful nomenclature of Tress et al. (2005), into a multidisciplinary or even cross-disciplinary project, in which there is a significantly lower level of integration among of the disciplines, and cross fertilization is minimal, if it exists at all. In some cases, when dealing with projects at the intersection of hydrology and biology, we do not even have the luxury to get to this initial stage of having to develop a common language. My experience over more than 25 years of research on the bioclogging of soils and aquifers (e.g., De Lozada et al. 1994; DeLeo \& Baveye 1997) and on other topics involving microorganisms (e.g., Falconer et al. 2012) — and this perception is confirmed by conversations with many colleagues is that it is extremely hard to get biologists to engage with non-biologists in interdisciplinary research efforts. Failed attempts in this respect can be very frustrating (Baveye 2009a), in particular because it forces nonbiologists to devote considerable efforts to learn a new body of knowledge and new skills, with many more trials and errors and in far more depth than if biologists were willing to collaborate in the work.

There seem to be several possible reasons for this apparent reluctance of biologists to engage in interdisciplinary efforts, particularly with hydrologists. One of them undoubtedly has to do with the profound lack of quantitative training of many biologists, which hinders them severely in any research effort in which the quantitative description of processes is an important step. Another clear reason is the current overwhelming fascination of many biologists with molecular methods, which at times clouds significantly the objectives that are being pursued in their research (e.g., Baveye 2009b). This 
fixation on methods, fueled by the possibilities this type of work affords in terms of very quick publication output and massive citations, has led over the last decade to a profound neglect of the type of objective-focused ecological research that would be needed to address many of the questions that for example hydrologists would like biologists to investigate with them. In this respect, the fact that this journal has accepted over the years to publish a number of articles on biohydrology appears as a very encouraging sign that, at least in one part of the world, some editors with vision are willing to go against the tide, and that there may yet be hope for positive engagement of biologists in biohydrological research efforts at a larger scale than is currently the case.

A second roadblock to increased interdisciplinary research at the intersection of hydrology and biology is related to the way much of this research is funded at the moment. Even though many funding agencies, be it in the US, in Europe, or elsewhere, claim to be very supportive of interdisciplinary research, virtually none has structures in place that are truly adapted to this type of endeavor. Available grants tend to be of short duration (3 years), their budgets modest, and their requirements high for significant results to be obtained almost from the onset of the funding period. This may be acceptable for very focused, mono-disciplinary research activities, but experience shows that these constraints are not adapted at all for interdisciplinary research projects, where the initial (and essential) step of developing a common language (and sometimes entirely new methodologies) takes time, during which actual research breakthroughs may be few and far between. As a result, a three-year timeframe is likely to be far too short, and longer grants should be the norm. In addition, interdisciplinary projects often need to involve larger groups of investigators working in very close proximity, which means that the budget allocations have to be substantially larger than they are at the moment and that it would not be practical to spread them thinly over many geographically-dispersed institutions (as is the case now with European grants). In this context, it would be wise for those working in interdisciplinary fields, like biohydrology, to try consistently to educate funding bodies and policy makers (not to forget the administrators of the institutions where we work, who seem in perpetual need of education) of the special challenges we face in carrying out our work. Hopefully, in a little while, this information effort will result in funding structures that are better adapted to what we need. Certainly, in other areas, some of our colleagues have been successful in convincing governments to invest huge amounts of financial resources into the construction of costly particle accelerators or into the launching of satellites to identify exoplanets many light years away from earth (Baveye et al. 2011). There is no real reason why we would not be successful as well.

The solutions to the two roadblocks that I have identified above are likely to be related. If the funding situation were more conducive to truly interdisciplinary research activities in biohydrology than it is at the moment, there may be more encouragement for biologists to engage. Conversely, if more biologists accept to engage, we may be able to make a better case to funding bodies to change their funding structures in a way that fosters more research at the confluence of biology and hydrology. In any event, it is worthwhile to try to overcome these roadblocks and to do everything we can to make the field prosper, especially given the fact that much of the research it involves is absolutely crucial to increase our chances of surviving the current climate change and to reaching a more sustainable society in the future.

\section{References}

Amiri B.J., Sudheer K.P. \& Fohrer N. 2012. Linkage between instream total phosphorus and land cover in Chugoku district, Japan: An ANN approach. J. Hydrol. Hydromech. 60: 33-44.

Baveye P.C. 2009a. Comment on "Conservation of protists: Is it needed at all?" by Cotterill et al. Biodiversity and Conservation 18: 503-505.

Baveye P.C. 2009b. To sequence or not to sequence the wholesoil metagenome? Nature Rev. Microbiol. 7: 756. DOI: 10.1038/nrmicro2119-c2

Baveye P.C., Rangel D., Jacobson A.R., Laba M., Darnault C. \& Otten W. 2011. From dust bowl to dust bowl: Soils are still very much a frontier of science. Soil Sci. Soc. Amer. J. 75: 2037-2048.

Budagovskyi A.I. \& Novak V. 2011. Theory of evapotranspiration 1. Transpiration and its quantitative description. J. Hydrol. Hydromech. 59: 3-23.

Dekker L.W., Hallett P.D., Lichner L., Novak V. \& Sir M. 2006. Introduction to biohydrology. Biologia 61: S223-S224.

DeLeo P.C. \& Baveye P. 1997. Factors affecting protozoan predation of bacteria clogging laboratory aquifer microcosms. Geomicrobiol. J. 14: 127-149.

De Lozada D.S., Vandevivere P., Baveye P. \& Zinder S. 1994. Decrease of the hydraulic conductivity of sand columns by Methanosarcina barkeri. World J. Microbiol. Biotechnol. 10: 325-333.

Falconer R.E., Houston A.N., Otten W. \& Baveye P.C. 2012. Emergent behavior of soil fungal dynamics: Influence of soil architecture and water distribution. Soil Sci. 177: 111-119.

Hallett P.D., Lichner L., Rajkai K., Schaumann G.E., Skvarenina J. \& Tesar M. 2009. Foreword to the thematic issue on Biohydrology. Biologia 64: 415-418.

Hallett P.D., Lichner L. \& Cerda A. 2010. Biohydrology: coupling biology and soil hydrology from pores to landscapes Preface. Ecohydrology 3: 379-381.

Hribik M., Vida T., Skvarenina J., Skvareninova J. \& Ivan L. 2012. Hydrological effects of Norway spruce and European beech on snow cover in a mid-mountain region of the Polana $\frac{1}{\text { Mts., Slovakia. J. Hydrol. Hydromech. 60: } 319} \frac{3}{32 .}$

Lichner L. 2013. Editorial and preface to thematic issue on biohydrology. J. Hydrol. Hydromech. 61: $1-2$.

Lichner L., Holko L., Zhukova N., Schacht K., Rajkai K., Fodor N. \& Sandor R. 2012. Plants and biological soil crust influence the hydrophysical parameters and water flow in an Aeolian sandy soil. J. Hydrol. Hydromech. 60: 309-318.

Nagy J. 2011. The effect of soil pH and precipitation variability during the growing season on maize hybrid grain yield in a 17 year long-term experiment. J. Hydrol. Hydromech. 59: 60-67.

Tress G., Tress B. \& Fry G. 2005. Clarifying integrative research concepts in landscape ecology. Landscape Ecol. 20: 479-493.

Received September 27, 2013 